\title{
\#USES
}

science for a changing world

Prepared in cooperation with the Florida Institute of Oceanography, Florida Fish and Wildlife Research Institute, and Florida Department of Environmental Protection

\section{Florida Coastal Mapping Program-Overview and 2018 Workshop Report}

By Cheryl J. Hapke, Philip A. Kramer, Elizabeth H. Fetherston-Resch, Rene D. Baumstark, Ryan Druyor, Xan Fredericks, and Ekaterina Fitos

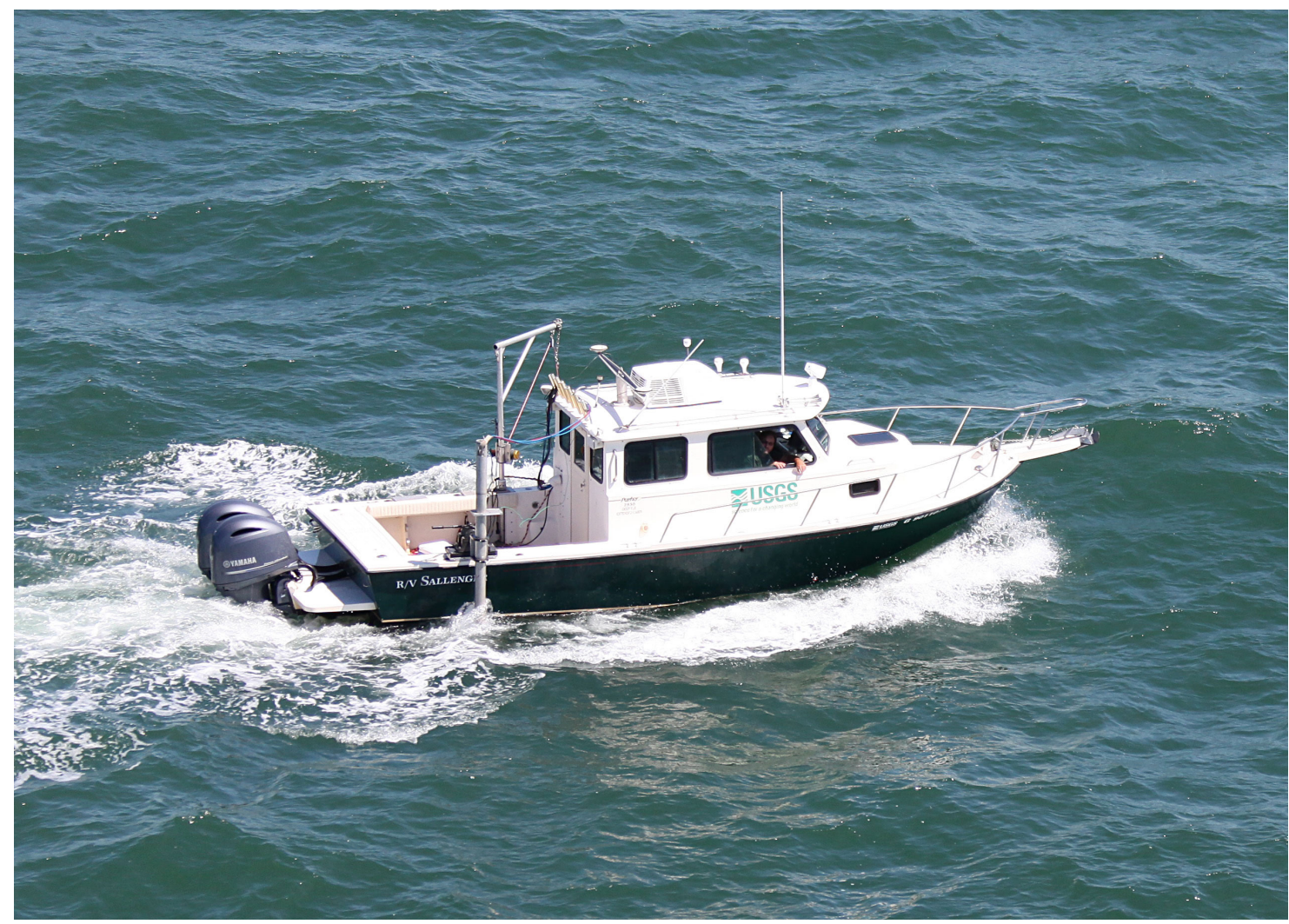

Open-File Report 2019-1017

U.S. Department of the Interior

U.S. Geological Survey 


\title{
U.S. Department of the Interior DAVID BERNHARDT, Acting Secretary
}

\author{
U.S. Geological Survey \\ James F. Reilly II, Director
}

U.S. Geological Survey, Reston, Virginia: 2019

For more information on the USGS-the Federal source for science about the Earth, its natural and living resources, natural hazards, and the environment-visit https://www.usgs.gov/ or call 1-888-ASK-USGS (1-888-275-8747).

For an overview of USGS information products, including maps, imagery, and publications, visit https://store.usgs.gov.

Any use of trade, firm, or product names is for descriptive purposes only and does not imply endorsement by the U.S. Government.

Although this information product, for the most part, is in the public domain, it also may contain copyrighted materials as noted in the text. Permission to reproduce copyrighted items must be secured from the copyright owner.

Suggested citation:

Hapke, C.J., Kramer, P.A., Fetherston-Resch, E.H., Baumstark, R.D., Druyor, R., Fredericks, X., and Fitos, E., 2019, Florida Coastal Mapping Program-Overview and 2018 workshop report: U.S. Geological Survey OpenFile Report 2019-1017, 19 p., https://doi.org/10.3133/ofr20191017. 


\section{Acknowledgments}

We are indebted to the participants of the Florida Coastal Mapping Program technical team, especially Brian Walker (Nova Southeastern University), who contributed substantial time and resources in assisting with the initial data inventory. We thank Matt Kendall, Tim Battista, and Ken Buja from the National Oceanic and Atmospheric Administration for helping to migrate the prioritization tool for use across Florida, and the Florida Wildlife Research Institute for hosting the January 2018 workshop.

We thank Sam Johnson, Jim Flocks and Noreen Buster (USGS) for thorough and helpful reviews of previous versions of this report, and Betsy Boynton (Cherokee Nation Technologies) for assistance with graphics. 



\section{Contents}

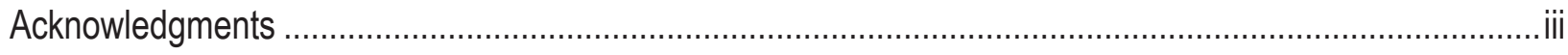

Introduction

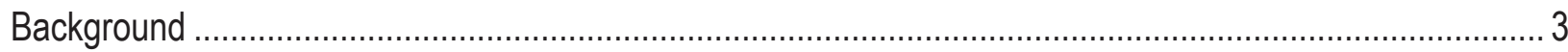

Florida Coastal Mapping Program Data Inventory ......................................................................... 4

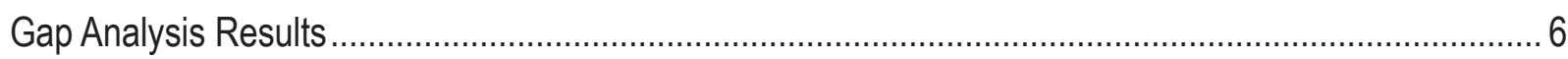

2018 Florida Coastal Mapping Program Workshop Discussions and Outcomes ......................................... 7

Existing Sea-Floor Mapping Data Inventory ................................................................................... 7

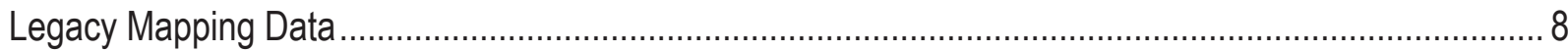

Mapping Discussions and Recommendations_Nearshore Areas .................................................... 8

Mapping Discussions and Recommendations_Shelf Area ............................................................ 9

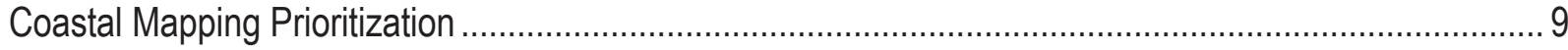

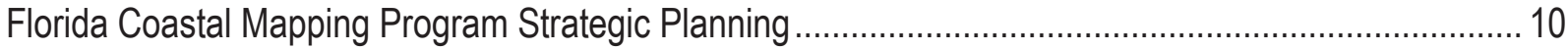

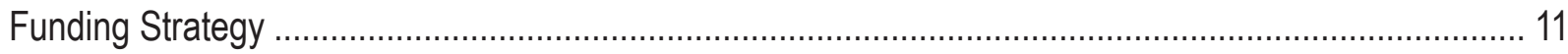

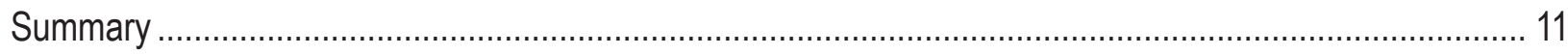

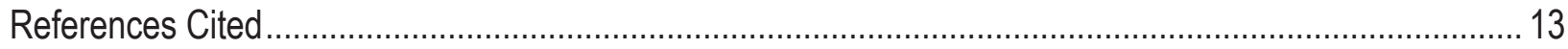

Appendix 1. Attendees of the January 2018 Workshop …………………......................................... 15

Appendix 2. Members of the Steering Committee and Technical Teams Steering Committee ................. 17

Appendix 3. Agenda of the January 2018 Workshop ……................................................................ 18

\section{Figures}

1. The approach to realize a sustained program for mapping Florida's coastal sea floor .....................2

2. Organizational chart for the Florida Coastal Mapping Program indicating co-chair and steering committee agencies ........................................................................................................

3. Map of high-resolution elevation data footprints on the Florida shelf ..........................................

4. Map showing the six inventoried regions of Florida considered in the inventory and prioritization ....6 


\section{Tables}

1. Results of the gap analysis of high-resolution elevation data for the six regions and depth-based geomorphic zones in Florida.

\section{Appendix Tables}

1.1. Attendees of the Florida Coastal Mapping Program Workshop, January 2018 ...............................15

2.1. Steering committee members and affiliations, 2017-18...........................................................17

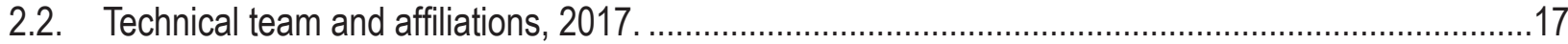




\section{Conversion Factors}

International System of Units to U.S. customary units

\begin{tabular}{lcl}
\hline \multicolumn{1}{c}{ Multiply } & By & \multicolumn{1}{c}{ To obtain } \\
\hline meter $(\mathrm{m})$ & Length & foot $(\mathrm{ft})$ \\
kilometer $(\mathrm{km})$ & 3.281 & mile $(\mathrm{mi})$ \\
kilometer $(\mathrm{km})$ & 0.6214 & mile, nautical (nmi) \\
meter $(\mathrm{m})$ & 0.5400 & yard (yd) \\
\hline & 1.094 & \\
\hline square meter $\left(\mathrm{m}^{2}\right)$ & Area & square foot $\left(\mathrm{ft}^{2}\right)$ \\
square kilometer $\left(\mathrm{km}^{2}\right)$ & 10.76 & acre \\
\hline
\end{tabular}

\section{Datum}

Vertical coordinate information is referenced to the North American Vertical Datum of 1988 (NAVD 88)

Horizontal coordinate information is referenced to the North American Datum of 1983 (NAD 83).

\section{Abbreviations}

$\begin{array}{ll}\text { 3D } & \text { three dimensional } \\ \text { BOEM } & \text { Bureau of Ocean Energy Management } \\ \text { DEM } & \text { digital elevation model } \\ \text { FCMaP } & \text { Florida Coastal Mapping Program } \\ \text { FDEP } & \text { Florida Department of Environmental Protection } \\ \text { FWRI } & \text { Florida Wildlife Research Institute } \\ \text { lidar } & \text { light detection and ranging } \\ \text { NOAA } & \text { National Oceanographic and Atmospheric Administration } \\ \text { SOnar } & \text { sound navigation and ranging } \\ \text { USACE } & \text { U.S. Army Corps of Engineers } \\ \text { USGS } & \text { U.S. Geological Survey }\end{array}$





\section{Florida Coastal Mapping Program-Overview and 2018 Workshop Report}

By Cheryl J. Hapke, ${ }^{1}$ Philip A. Kramer, ${ }^{2}$ Elizabeth H. Fetherston-Resch, ${ }^{2}$ Rene D. Baumstark, ${ }^{3}$ Ryan Druyor, ${ }^{3}$ Xan Fredericks, ${ }^{1}$ and Ekaterina Fitos ${ }^{4 t}$

\section{Introduction}

High-resolution mapping of the sea floor provides essential information for managing ocean resources, growing economic opportunities, enhancing national security and navigational safety, and improving coastal access with benefits to stakeholders and citizens. High-resolution mapping is particularly important given that Florida has the longest coastline in the contiguous United States $(2,170$ kilometers $[\mathrm{km}])$ and an adjacent continental shelf that is highly biologically diverse and productive (Balcom and others, 2011).

Florida's ocean and coastal resources, its "Blue Economy," are the main drivers of economic growth in the State, representing 79 percent of the State's economic activity per year (www.floridaoceanalliance.org). The coastal zone is home to 80 percent of Florida's population and contains $1,900 \mathrm{~km}$ of sandy beaches that support economically important recreation and tourism for some 22 million visitors each year (Klein and Osleeb, 2010), placing Florida's coastal waters among the most valuable coastal zones in the Nation. The Florida sea floor also supports an offshore sand mining industry that is essential to renourish beaches and support coastal construction efforts.

To support informed and strategic decisions, there is continual need for high-quality information on the coast and adjacent sea-floor areas. High-resolution data are critical for locating natural resources (for example, sand and habitats), assessing the health of fishery populations, understanding coastal vulnerability and hurricane impacts, and evaluating performance of restoration projects. Florida could benefit for decades and vastly improve ocean resource management by investing in state-of-the-art high-resolution bathymetric data and associated derived map products (for example, navigational charts, marine habitats, marine geology, offshore sand resources, offshore hazards, and submerged archaeological resources).

The science and resource management community identified the need to improve the resolution and extent of sea-floor mapping in Florida in 2006. The Florida Oceans and Coastal Resources Council, established by the Florida Legislature in 2005 (Florida Statutes 161.70-161.76) identified ocean mapping as a top research priority for the State, with the objective of producing present-day highest-resolution bathymetric maps, identifying physical geologic setting (sediment/rock) and submarine aquatic vegetation with the goal of mapping the entire State's waters by 2015 (Robbins and others, 2008). In addition, a 2007 Florida sea-floor mapping workshop was organized by the U.S. Geological Survey (USGS), Florida Department of Environmental

\footnotetext{
${ }^{1}$ U.S. Geological Survey.

${ }^{2}$ Florida Institute of Oceanography, University of South Florida.

${ }^{3}$ Florida Wildlife Research Institute, Florida Fish and Wildlife Conservation Commission.

${ }^{4}$ Florida Department of Environmental Protection.
} 
Protection (FDEP), and Southeastern Regional Partnership for Planning and Sustainability to bring together stakeholders and identify priority areas for mapping (Robbins and others, 2008).

Despite the 2007 workshop recommendations for improved coordination for coastal mapping, State and Federal funding, and a clearly defined leadership body or coordinating entity, there has been little progress in achieving the 2015 State's waters mapping goal. Several smaller and independent sea-floor mapping efforts have been done by assorted Federal, State, and academic institutions; however, these have been disbursed, small-scale, and short-term efforts tied to specific grants, projects, or events (for example, hurricanes).

In 2017, the USGS and the Florida Institute of Oceanography launched an effort to rekindle the discussion about coastal and sea-floor data in Florida through the Florida Coastal Mapping Program (FCMaP). FCMaP consists of Federal and Florida State agencies and institutions with a common mission to (1) assess and inventory existing data; (2) undertake a stakeholder-driven prioritization process for identifying highest priority mapping needs for both science and management; (3) engage the public to raise awareness of the value of modern, high-resolution sea-floor data; and (4) secure funding from public and private sectors to map all of Florida's coastal waters from the shore to the shelf edge. The strategic plan to accomplish this mission is presented in figure 1. To accomplish this goal, a steering committee composed of Federal and State agencies are working together, essentially as a working group, to coordinate ongoing and future mapping efforts, to engage with stakeholders through regional and statewide workshops and other communications to prioritize new data collection, and to develop a program-funding strategy. The implementation of the tasks outlined in figure 1 is undertaken by various technical teams which are stood up until a task reaches completion. The technical teams have a coordinator(s), generally a member(s) of the steering committee, who interfaces between the work of the technical team and reports to the steering committee. The initial funding investment, provided as support from the steering committee agencies, is to develop the program and to build a robust strategy for sustained funding.

This report provides the background, history, and structure of FCMaP; an overview of the inaugural January 2018 workshop; and an initial strategy for accomplishing the goal of acquiring consistent, high-resolution sea-floor data for Florida's coastal waters from the shore to the shelf edge during the upcoming decade. The result could support numerous applications and benefit

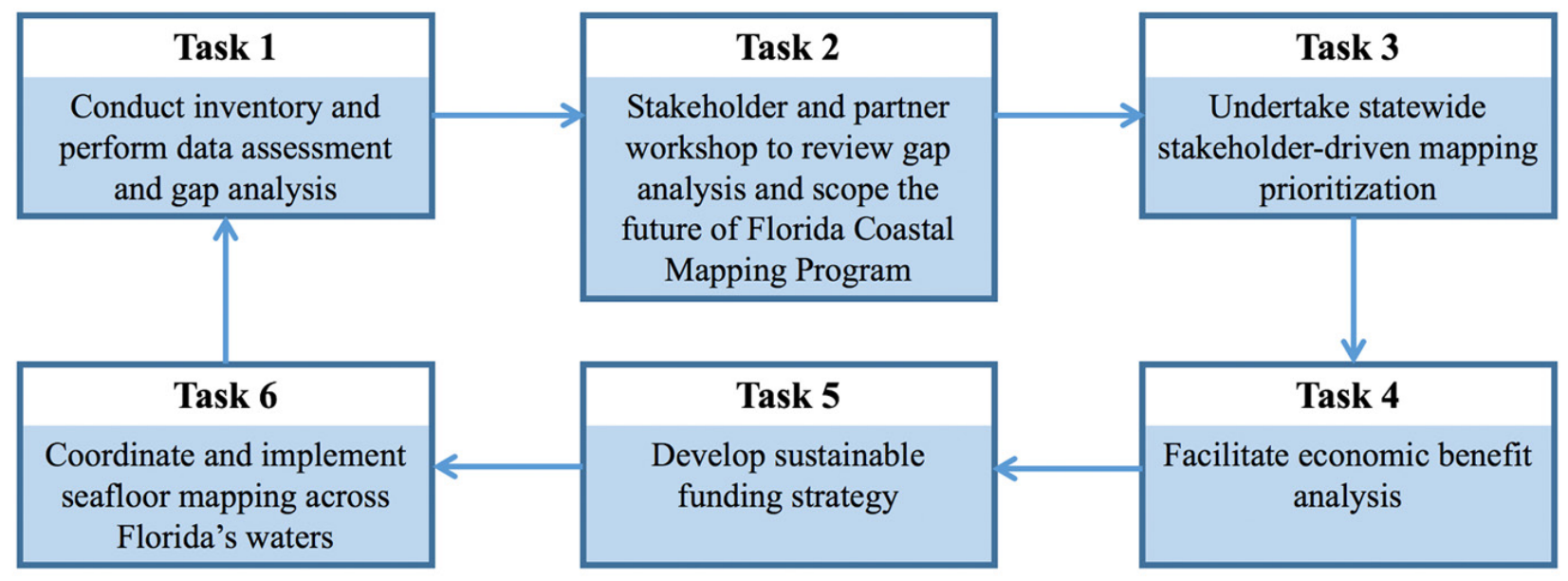

Figure 1. The approach to realize a sustained program for mapping Florida's coastal sea floor. Each task is implemented by a technical team, stood up as required by the FCMaP steering committee. 
Vision-Accessible, high-resolution sea-floor data of Florida's coastal waters to support infrastructure, benthic habitat mapping, restoration projects, resource management, emergency response, and coastal resiliency and hazard studies for the citizens of Florida.

Mission - Coordinate across Federal and Florida State agencies, and other stakeholders, to build a comprehensive understanding of Florida's coastal sea floor.

the citizens of Florida for years to come. The most important component of FCMaP that will ensure future success is developing and implementing a long-term funding strategy, which is envisioned to be a public-private initiative, similar to the successful funding strategy between Federal and State entities of the California Seafloor Mapping Program (Johnson and others, 2017), with some level of contribution from private industry as well.

\section{Background}

Most of Florida's nearshore and shelf zones have been mapped previously; however, most of these data are outdated and of low resolution. For example, nautical charts for large sections of the Florida shelf incorporate lead-line bathymetric readings from the 1800s and have data points existing at a density of 1 to 2 soundings per 100 square meters or less. Although useful for some hydrographic charting applications, the low-resolution data have limited utility for port managers, ocean resource managers, coastal zone decision makers, marine scientists, and recreational and commercial fishing stakeholders.

Mapping technologies, specifically topobathymetric light detection and ranging (lidar) and multibeam sound navigation and ranging (sonar) bathymetry, have rapidly improved during the last decade, making regional-scale, high-resolution elevation data collection more efficient and cost-effective. Large-scale mapping efforts are possible, and State, national, and even international mapping programs provide valuable examples of multiagency collaborative mapping initiatives. In the United States, the California Seafloor Mapping Program is a Federal-State cooperative created and funded to create comprehensive bathymetric, geologic, and habitat maps for all of California's State waters (Johnson and others, 2017; https://www.usgs.gov/centers/ $\mathrm{pcmsc} / \mathrm{science} / \mathrm{california-seafloor-mapping-program}$ ). The Massachusetts State Office of Coastal Zone Management has a different cooperative program with the USGS to conduct geologic mapping of the sea floor targeting specific areas of interest without the objective of mapping all State waters (https://woodshole.er.usgs.gov/project-pages/coastal_mass/index.html). Internationally, the Integrated Mapping for the Sustainable Development of Ireland's Marine Resources program is a 20-year, two-phase initiative between the Geological Survey of Ireland and the Marine Institute with a goal of systematically producing maps of physical, chemical, and biological features of Ireland's sea floor (https://www.infomar.ie/about/). Overarching all this is a new initiative called Seabed 2030, started in 2017 by the Nippon Foundation-General Bathymetric Chart of the Oceans, with the goal of facilitating complete mapping of the global sea floor by 2030 (https://seabed2030.gebco.net/). All the examples described above, along with this FCMaP effort, will contribute to the overall goal of Seabed 2030. 
FCMaP was formally established in January 2017 with the formation of a steering committee co-chaired by the USGS and Florida Institute of Oceanography. At the time, three State and four Federal agencies agreed to join the steering committee and to identify staff within their institutions to participate on a technical working group team that would undertake a data inventory and gap analysis. The technical team included additional expertise from academic institutions with strong mapping programs (fig. 2), and its primary purpose was to complete the inventory and analysis, after which it was dissolved. After the first FCMaP workshop in January 2018, the steering committee expanded to include Florida Division of Emergency Management and the State Geographic Information Officer of the Florida Department of Environmental Protection.

\section{Florida Coastal Mapping Program Data Inventory}

The FCMaP inventory and gap analysis technical team (appendix 2), comprised of technical staff identified from within each of the steering committee agencies, plus academic partners, was formed to produce an inventory of existing data. The academic partners for the inventory technical team were the University of South Florida College of Marine Science, Nova Southeastern University, University of Miami Rosenstiel School of Marine and Atmospheric Science, and Florida Atlantic University. The team was charged with compiling the extent and quality of existing Florida sea-floor data. Initial efforts included defining the extent

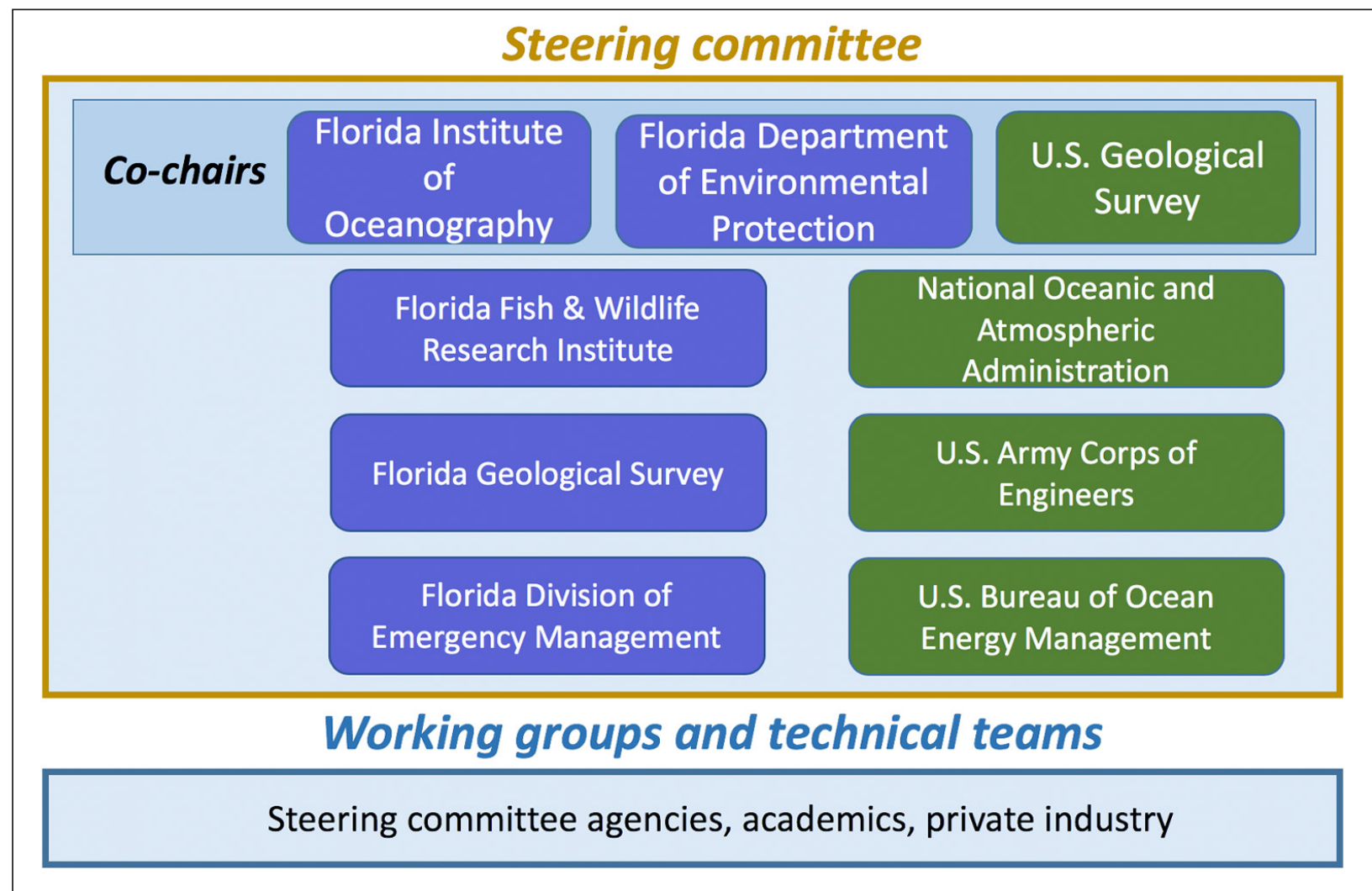

Figure 2. Organizational chart for the Florida Coastal Mapping Program indicating co-chair and steering committee agencies. The steering committee is the overseeing body of the program; technical teams comprised of staff from steering committee agencies, academics, and potentially private industry, are stood up as needed to accomplish the various tasks in the strategic plan (see fig. 1 above). 
or boundary of the inventory area around Florida as extending from the shoreline out to the continental shelf edge and describing all data types consistent with the purpose and need of the inventory. In brief, the technical team's work consisted of developing a framework for organizing Florida's mapping data, collecting information on the footprints of existing data, compiling the footprints and associated metadata in a single map service, and performing an initial analysis of mapping gaps.

The bulk of the effort was spent identifying locations and collecting the footprints for existing high-resolution sea-floor data for Florida's coastal and marine waters, including topobathymetric lidar or high-resolution bathymetric multibeam sonar. The minimum mapping resolution requirement for bathymetric datasets was set at one point per 10-square-meter area of sea floor. Sea-floor datasets were identified and inventoried, and the spatial extent boundaries (also known as footprints) were compiled into a geographic information system database and mapping portal hosted by the Florida Fish and Wildlife Research Institute (FWRI; fig. 3).

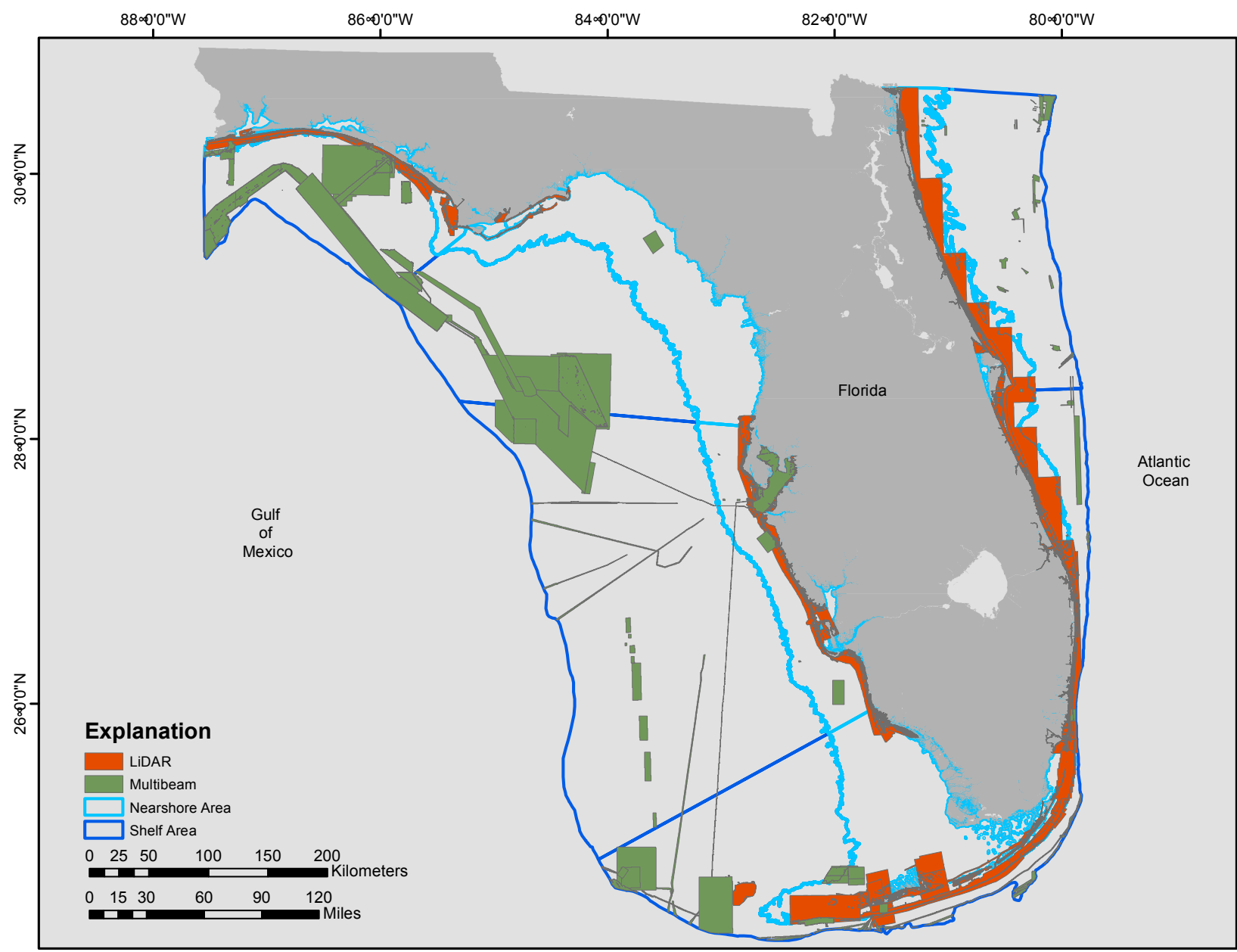

Figure 3. Map of high-resolution elevation data footprints (light detection and ranging [lidar] and multibeam) on the Florida shelf. More than 80 percent of Florida's shelf elevation has not been mapped. The light blue line outlines the area from the shoreline to the 20-meter isobath, and the dark blue outer boundary is the edge of the continental shelf. The individual lines on the west Florida shelf are individual track lines of multibeam bathymetry. Note that the footprints shown may not represent the entirety of a given survey but only those data that fall within the Florida Coastal Mapping Program zone. 


\section{Gap Analysis Results}

After compiling existing data footprints (fig. 3), the inventory and gap analysis technical team delineated six geographic regions: Panhandle, Big Bend, West Florida Peninsula, Keys, Southeast Florida, and Northeast Florida (fig. 4). The regions were determined based on variations in physiography, coastal geomorphology, and resource management needs. Regions were further divided by depth based on the differing sensor and survey design requirements: nearshore (shoreline out to 20-meter [m] depth) and shelf (20-m depth to the continental shelf break). The gap analysis revealed that less than 20 percent of Florida waters have been mapped to modern bathymetric standards. The nearshore zone has better coverage ( 27 percent) than the shelf zone (about 16 percent).

The results of the gap analyses for the different geographic regions and depth-based geomorphic zones (nearshore and shelf) are provided in table 1. The two areas with the most high-resolution data are the nearshore zone of the Southeast Florida region (84 percent) and the shelf zone of the Panhandle region (39 percent). Conversely, the two areas with the least high-resolution data are the nearshore zone of the Big Bend region and the shelf zone of the Northeast Florida region with 3 and 4 percent, respectively. In summary, figure 4 and table 1 document that substantial parts of the Florida's sea floor remain unmapped.

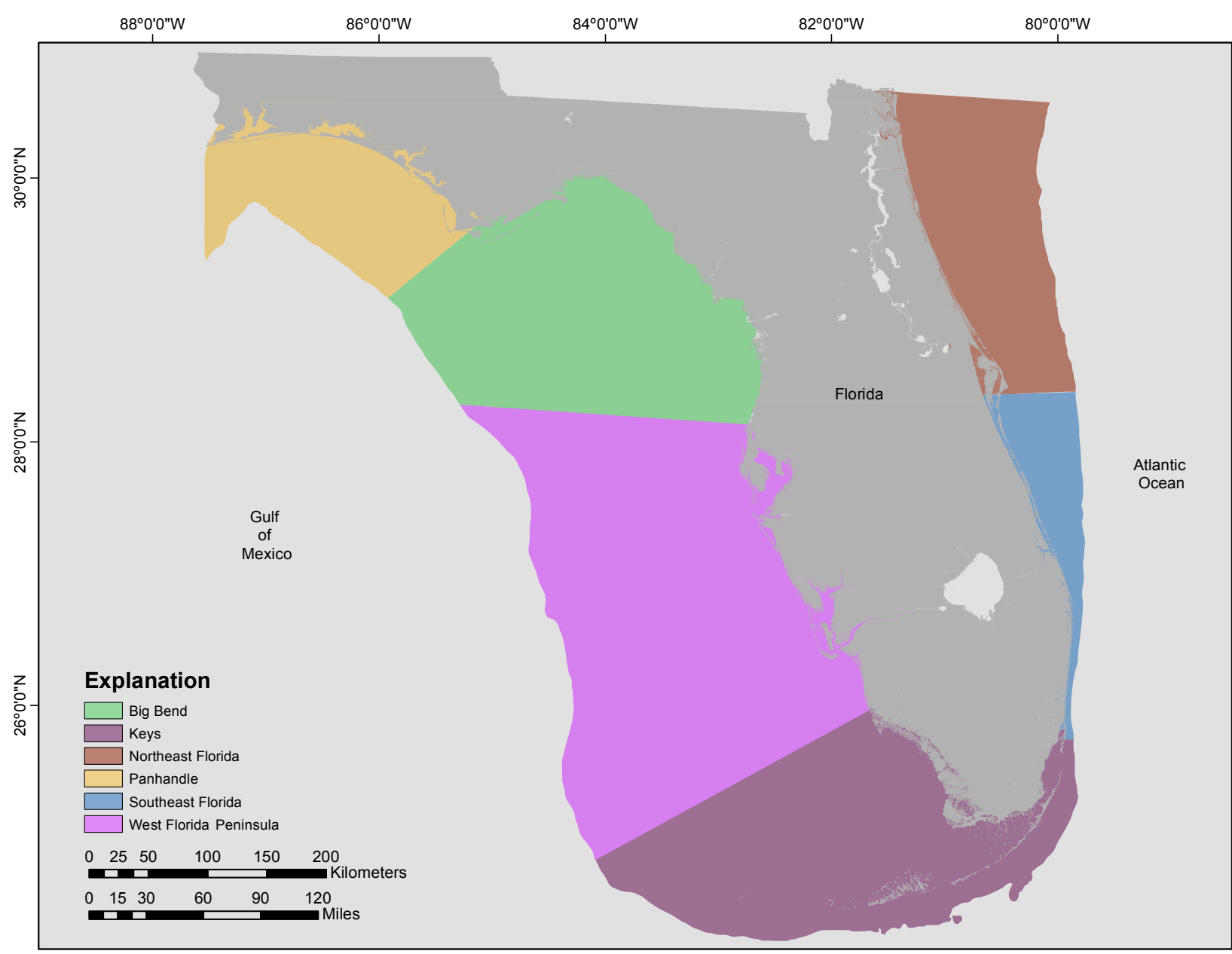

Figure 4. Map showing the six inventoried regions of Florida considered in the inventory and prioritization. 
Table 1. Results of the gap analysis of high-resolution elevation data for the six regions and depth-based geomorphic zones in Florida.

\begin{tabular}{lcc}
\hline \multicolumn{1}{c}{ Region } & $\begin{array}{c}\text { Percent mapped } \\
\text { (nearshore) }\end{array}$ & $\begin{array}{c}\text { Percent mapped } \\
\text { (shelf) }\end{array}$ \\
\hline Panhandle & 43 & 39 \\
Big Bend & 3 & 16 \\
West Florida Peninsula & 28 & 6 \\
Keys & 27 & 19 \\
Southeast Florida & 84 & 20 \\
Northeast Florida & 61 & 4 \\
\hline
\end{tabular}

\section{Florida Coastal Mapping Program Workshop Discussions and Outcomes}

A FCMaP workshop, held January 9 to 11, 2018, at the FWRI in Saint Petersburg, Florida, was attended by more than 75 representatives of State and Federal agencies, academic institutions, private industry, and nongovernmental organizations (see appendix 1 for attendee list). The goals of the workshop were fourfold:

- Examine existing sea-floor mapping data inventory with participants and identify missing data.

- Identify sea-floor mapping products needed by most stakeholders.

- Discuss future nearshore and shelf mapping needs and recommendations.

- Determine the appropriate role for the FCMaP.

Introductory sessions provided an overview of high-resolution sea-floor mapping; provided an overview of specific agency activities and capabilities; and featured several distinguished speakers highlighting sea-floor mapping efforts on the West Florida Shelf, California, and processes developed by the National Oceanic and Atmospheric Administration (NOAA) to identify mapping priorities (see appendix 3 for workshop agenda). Links to the presentations are available on the FCMaP web page: (https://www.usgs.gov/centers/spcmsc/science/florida-coastal-mappingprogram). The bulk of the workshop divided the participants into nearshore and shelf working groups to review and provide feedback on assembled mapping datasets, to develop mapping recommendations, and to provide input on the structure and future directions of the FCMaP initiative.

\section{Existing Sea-Floor Mapping Data Inventory}

Workshop participants were given an opportunity to review existing datasets gathered and assembled into the FWRI mapping portal by the FCMaP technical team. The mapping inventory provides polygons of coverage and metadata for acoustic data, including multibeam and sidescan sonar bathymetry, optical topobathymetric lidar, and subbottom, high-resolution seismic-reflection profiles (compressed high-intensity radiated pulse and boomer data). The review covered about 75 mapping datasets with sufficient information to be fully cataloged. An additional 32 mapping datasets had insufficient metadata to determine the spatial accuracy. At least 12 new high-resolution mapping datasets, sources, or both of mapping data were identified by participants at the workshop. 


\section{Legacy Mapping Data}

Legacy datasets are those that might be improved in quality and resolution by modern digital processing. These datasets were generally collected before the 2000s and are not included in the figure 3 data inventory. It was acknowledged that reprocessing of some legacy data could be important for mapping habitats and for sea-floor change detection. However, much reprocessing may be difficult and time consuming because of old formats, lack of spatial accuracy, and lack of digital records. Ultimately, the group determined that the time required for a large-scale effort to discover and make use of legacy datasets would be better spent on other mapping activities.

There was a subsequent conversation about how existing data such as single-track lines of bathymetry and side-scan sonar and subbottom data could be used to infer habitat type in a way that was informative. The group determined that additional work compiling the location of such datasets might prove worthwhile.

\section{Mapping Discussions and Recommendations-Nearshore Areas}

The participants reviewed printed maps displaying the inventory of existing footprints compiled by the technical team in the nearshore 0-to-20-m area (topobathymetric lidar or bathymetric sonar). The group recommended modifications to some of the regional boundaries, which were annotated on the paper maps for future update, and suggested other potential data sources, such as the Coast Guard, the Navy, MacDill Air Force Base, various port authorities, and counties. The FDEP (specifically the Beaches Program) shared that they conduct postnourishment surveys to $30-\mathrm{m}$ water depth of borrow areas and any hard bottom or seagrass areas that may be affected by the borrow pit. FDEP works with the Bureau of Ocean Energy Management (BOEM) and U.S. Army Corps of Engineers (USACE) for data collection and offered to provide FCMaP with the nourishment schedule. These data may fill some of the gaps. It was also noted that private-sector companies, such as Fugro and others, have collected elevation data for a diverse clientele and that it might be possible to put some of these data (with appropriate metadata) into the public domain.

The primary sensors used to collect sea-floor elevation data in the nearshore zone are topobathymetric lidar and multibeam sonar. Side-scan sonar and high-resolution, seismic-reflection systems also provide valuable information critical to habitat and resource mapping. The nearshore group participants proposed mapping the nearshore (0-to-20-m) zone with topobathymetric lidar data at a high enough point density to support a 1-m resolution digital elevation model (DEM). This capability depends on sufficient water clarity to support laser penetration and bottom reflectivity. In regions other than the Keys, topobathymetric lidar may not be effective because of water turbidity, resulting in a reliance on multibeam sonar to complete data acquisition. For any topobathymetric lidar surveys flown as part of FCMaP, it will greatly improve the quality and water depth penetration if collection occurs during optimal seasonal and weather conditions (that is, dry season and low wind conditions). Multibeam sonar surveys for FCMaP could achieve a high enough data density to ideally support a 1-m resolution DEM and minimally support a 3-m resolution DEM. The group discussed and prioritized the primary needs and applications of high-resolution bathymetry in nearshore environments. The list included 25 applications of which the top ranked were coastal restoration and preservation, habitat and living resource management, baseline geologic mapping and geomorphology, and coastal inundation. Submerged archaeological artifacts were also recognized as potentially important, although this group of stakeholders was not represented at the workshop. 


\section{Mapping Discussions and Recommendations-Shelf Area}

Participants interested in the shelf area (20 to $200 \mathrm{~m}$ ) examined the data footprints compiled by the technical team in this region. The consensus was that the $200-\mathrm{m}$ limit should be deeper, at least for assembling the footprints of what has been mapped, even if the effort to achieve a completed map is limited to the $200-\mathrm{m}$ end point. The group made a number of recommendations for additional sources that may yield other data including the following: National Marine Fisheries Service Pascagoula lab; University of South Florida's Continental Shelf Characterization, Assessment, and Mapping Project project; National Centers for Environmental Information data footprints that extend off the shelf edge; BOEM deep water bathymetry; Okeanos Explorer data from planned 2018 cruises; Natural Resources Damage Assessment data in the NOAA Data Integration Visualization Exploration and Reporting Explorer database; and data collected by contractors for permitting and other purposes that could be placed in the public domain.

The group identified important resources in water depth greater than $20 \mathrm{~m}$ such as fish, wildlife, biotic and abiotic benthic habitats, and sand resources for beach restoration and other projects (note: this list reflects the expertise and mandate of the agencies and people at the workshop and is not necessarily comprehensive). Important applications of mapping in the shelf area include managing natural resource; identifying cultural resources, paleoshorelines, and freshwater springs; siting of fiber optic cables and other offshore infrastructure; and predictive modeling for undersea landslides, storm surge, and sediment transport. The group decided to adopt the International Hydrographic Organization standards for mapping for FCMaP and acknowledged that new data acquisition with modern instrumentation will generally exceed those standards.

The primary sensors used for collecting sea-floor data in waters deeper than $20 \mathrm{~m}$ are multibeam, sidescan, and subbottom compressed high-intensity radiated pulse sonar systems. Ground-truthing of the geophysical data can be done using a variety of approaches including sediment samples, vibracores, dredging records, and by video or still imagery taken using autonomous unmanned vehicles or remotely operated vehicles. The amount of ground-truthing coverage needed to generate derivative habitat products and geologic map models will vary according to the character of the sea floor. It was noted that the existing FCMaP inventory did not include information on associated ground-truthing activities. Separating ground-truthing efforts from the initial hydrographic and geologic data capture was deemed to be more efficient and targeted than combining them into a single cruise. This is consistent with the data collection strategy in California's Seafloor Mapping Program (Johnson and others, 2017). Ground-truthing of data for habitat mapping is not unique to the shelf zone and is a necessary component of habitat mapping in nearshore areas as well.

The cost of collecting elevation data, follow-up ground-truth surveys, and subsequent production of habitat maps is estimated at $\$ 1,000$ per square kilometer. Given the scale of the Florida shelf area, the overall cost is likely prohibitive for any one source of funding. A feasible approach might involve large-scale collection of hydrographic and geologic data by private-sector contractors, followed by ground-truthing and product development (including habitat classification) by State and Federal agencies and academic institutions.

\section{Coastal Mapping Prioritization}

Regional prioritization is being conducted by the FCMaP across the State during 2018 and 2019, via a technical team lead by coordinators at USGS and FWRI. To conduct the 
prioritization with direct input from managers, planners, and decision makers, a series of workshops are being held within each of the six Florida regions (fig. 3). At the workshops, representatives from multiple Federal, State, local, academic, and private entities are introduced to FCMaP and engage in discussion of the relevance of high-resolution sea-floor maps to their region's science and management needs. The workshops serve not only as a mechanism with which to conduct the prioritization process based on regional needs but also provide a dialog with regional communities about FCMaP and the importance of their support moving forward. It is envisioned that workshop attendees also will serve as mapping working groups for their regions and be engaged throughout the life of FCMaP.

The prioritization process, first required adapting a tool developed by NOAA (Kendall and others, 2018; Battista, and others, 2017) to be applicable for use across Florida. The tool adaptation was undertaken by technical team leads at FWRI. The tool is an online geospatial widget that allows users to identify specific areas of highest priority, indicate desired ancillary data needs (beyond elevation), and justify why the identified areas are priorities. For the tool, each region of Florida is divided into 10-square-kilometer grids that extend from the shoreline to the shelf edge. The widget is designed such that each agency representative is allotted an equal number of "coins" that they assign to the grid cells to indicate priority. The number of coins for each region is equal to 20 percent of the total number of cells in the grid, and the total number of coins that can be placed in any given cell is 10 percent of the total number of coins. For example, the Big Bend Region has 619 cells; therefore, the number of coins allotted to each user is 123 , and the maximum number of coins allowed per cell is 12 . Once coins are placed in a cell, the user selects primary, secondary, and tertiary justifications for their priority mapping need. The choices for justification include habitat mapping and coastal geomorphology, resource management, fishing and fisheries, recreation, navigation, scientific research and education, and cultural and historical resources. The categories are broad so that they can be assessed along with the geospatial prioritization. Once all entities have populated the tool, data analytics are used to generate a cumulative prioritization for the region that can be displayed as a map product, and the associated justifications for the mapping need are statistically evaluated.

\section{Florida Coastal Mapping Program Strategic Planning}

FCMaP is a coordinating entity, essentially a working group, for mapping in Florida's coastal and marine waters. Part of the FCMaP strategic implementation plan (fig. 1) includes undertaking a prioritization process, led by a technical team, to hold mapping prioritization workshops in each of the six geographic regions of Florida with local and regional stakeholders. Additional priority activities include an economic benefit analyses for high-resolution sea-floor mapping; and facilitation of the State, Federal, academic, and private partnerships necessary to achieve the shared goal of high-resolution mapping. Accomplishing FCMaP goals will require sustained funding sources and substantial buy-in from State and Federal agencies and the private sector.

After the January 2018 workshop, steering committee members recognized that there was a need for dedicated program leads, or coordinators, to maintain momentum for implementing tasks such as the prioritization process. The coordinator(s) role is to lead the technical team activities, including organizing and facilitating the prioritization workshops, and overseeing the prioritization implementation and analysis. The steering committee will continue to stand up technical teams and identify appropriate coordinators, and lead the development of a full program and funding strategy. 


\section{Funding Strategy}

A high priority for FCMaP is developing or facilitating an economic benefit analysis to determine return on investment of the program that can be used to communicate the value of Florida mapping products. Benefit-to-cost ratios developed for other similar coastal mapping programs in Ireland (https://www.infomar.ie/about/) and the United Kingdom (http://www.maremap.ac.uk/index.html) determined that the return on modern generation sea-floor mapping is between 4:1 and 6:1. The FCMaP expects Florida, whose economy is heavily reliant on a healthy coast and ocean, to fall within the upper range of a similar assessment. The argument can be made that in many cases, this is a one-time investment because the derived benefits will be useful for several decades.

The vision for funding is a public-private initiative wherein state and federal governments, and private industry commit to contribute funding over a 10 -year program period. This will require engagement with state and federal governments. The new St. Petersburg Joint Institute for Gulf of Mexico Studies is proposing a \$70 million initiative for Florida coastal mapping that would align with the Gulf coast regions of FCMaP.

There are several potential sources of federal funding, the largest of which is associated with three-dimensional (3D) Nation (https://communities.geoplatform.gov/ngda-elevation/ 3d-nation-study/), a joint NOAA-USGS effort to unify elevation standards and objectives for the Nation. Whereas previous similar studies and funding programs focused solely on topographic elevation from lidar data, 3D Nation includes bathymetric elevation data as well. Recommendations for funding and priorities will be made once the 3D Nation Elevation Requirements and Benefits Study is complete. FCMaP members have participated in the Elevation Requirements and Benefits Study, and the program is well-positioned to receive support via 3D Nation if funding is appropriated through the Federal Government. In addition to 3D Nation, BOEM and the USACE have programs to map mineral resources on the U.S. continental shelf, largely for beach sand nourishment projects. Given the lack of high-resolution sea-floor information, coordinated mapping of Florida's shelf stands to benefit the needs of both agencies.

Lastly, it will be important to engage the private sector as a source of funding for the FCMaP. The energy industry may be a key partner. For instance, with increasing interest in wind energy, modern high-resolution bathymetric data will be required for exploring and identifying appropriate sites for wind farms. Although there is presently a moratorium on oil and gas development on Florida's continental shelf, these energy sectors may be interested in baseline exploration in the event the moratorium is lifted or modified when it is evaluated in 2022.

\section{Summary}

The Florida Coastal Mapping Program is a nascent but highly relevant program that has the potential to greatly enhance the "Blue Economy" of Florida by coordinating, facilitating, and implementing sea-floor mapping efforts and aligning partner and stakeholder activities for increased efficiency and cost reduction. The existing lack of modern, high-resolution data of Florida's sea floor is striking - less than 20 percent of the entire coastal zone from the shoreline to the edge of the continental shelf has the type of data coverage that FCMaP is promoting. Sustained acquisition of modern coastal mapping information for Florida may improve management of resources and sustained coordination may reduce costs by eliminating redundancy. Economic growth could be aided by improved data to support emerging sectors such as aquaculture and renewable energy. 
The present focus of the Florida Coastal Mapping Program is on modern, high-resolution bathymetric and coastal topobathymetric data, which can be immediately used to update navigational charts and identify navigation hazards, provide fundamental baseline data for scientific research, and provide information for use by emergency managers and responders. Derivative products include identifying sand resources for beach nourishment, creating vastly improved models for coastal erosion and flooding, identifying coastal springs, and creating benthic habitat maps. The uses and applications of the data generated could grow over time, and in many cases the benefit of the investment could last for decades. FCMaP is supported by nine agencies that contribute to the steering committee, which is led by co-chairs from USGS, FDEP, and FIO. In order to implement various tasks identified in the strategic plan, the steering committee stands up and oversees technical teams that undertake the work necessary to accomplish each task, such as data gap analysis or mapping prioritization. FCMaP establishes and maintains working relationships with a broad array of partners and stakeholders who may be users of data collected as part of the FCMaP effort or may be funding entities.

The vision of FCMaP, to facilitate accessible, high-resolution sea-floor data of Florida's coastal waters to support infrastructure, benthic habitat mapping, restoration projects, resource management, emergency response, and coastal resiliency and hazard studies for the citizens of Florida, can be achieved by the sustained commitment of the FCMaP steering committee agencies, and buy-in from other partners and the private sector. A program of sustained mapping of Florida's rich coastal waters may provide long-lasting benefit to the citizens and natural resources of Florida. 


\section{References Cited}

Balcom, B.J., Biggs, D.C., Hu, C., Montagna, P., and Stockwell, D.A., 2011, A comparison of marinine productivity among outer continental shelf planning areas, OCS Study BOEMRE 2011019 Final Report, 358 p. [Also available at https://www.boem.gov/ESPIS/5/5121.pdf.]

Battista, T., Buja, K., Christensen, J., Hennessey, J., and Lassiter, K., 2017, Prioritizing seafloor mapping for Washington's Pacific coast: Sensors, v. 17, no. 4, 23 p. [Also available at https://doi. org/10.3390/s17040701.]

Johnson, S.Y., Cochrane, G.R., Golden, N.E., Dartnell, P., Hartwell, S.R., Cochran, S.A., and Watt, J.T., 2017, The California Seafloor Mapping Program-Providing science and geospatial data for California's State Waters: Ocean and Coastal Management, v. 140, p. 88-104. [Also available at https://doi.org/10.1016/j.ocecoaman.2017.02.004.]

Kendall, M.S., Buja, K., and Menza, C., 2018, Priorities for lakebed mapping in the proposed Wisconsin-Lake Michigan National Marine Sanctuary: Silver Spring, Md., National Oceanic and Atmospheric Administration Technical Memorandum NOS NCCOS 246. 24 p. [Also available at https://doi.org/10.7289/V5/TM-NOS-NCCOS-246.]

Klein, Y.L., and Osleeb, J., 2010, Determinants of coastal tourism-A case study of Florida Beach Counties: Journal of Coastal Research, v. 26, no. 6, p. 1149-1156. [Also available at https:// doi.org/10.2112/JCOASTRES-D-09-00152.1.]

Robbins, L., Wolfe, S., and Raabe, E., 2008, Mapping of Florida's coastal and marine resources - Setting priorities workshop: U.S. Geological Survey Open-File Report 2008-1157, 32 p. [Also available at https://www.researchgate.net/profile/Ellen_Raabe/publication/242610406_ Mapping_of_Florida's_Coastal_and_Marine_Resources_Setting_Priorities_Workshop/ links/544935ba0cf2f63880810a72.pdf.] 


\section{Appendix 1. Attendees of the January 2018 Workshop}

Table 1.1. Attendees of the Florida Coastal Mapping Program Workshop, January 2018.

[BOEM, Bureau of Ocean Energy Management; DEP-FGS, Department of Environmental Protection, Florida Geological Survey; ERT, Earth Resources Technology, Inc.; FDEP, Florida Department of Environmental Protection; FIO, Florida Institute of Oceanography; FL DOS, Florida Department of State; FL, Florida; FSU, Florida State University; FWC, Florida Fish and Wildlife Conservation Commission; FWRI, Fish and Wildlife Research Institute; GOMA, Gulf of Mexico Alliance; IDS, INNOVIM Defense Services; NMFS, National Marine Fisheries Service; SERO, Southeast Regional Office; NOAA, National Oceanic and Atmospheric Administration; IOCM, Integrated Ocean and Coastal Mapping; NW, Northwest; NOVA, Nova Southeastern University; NPS, National Park Service; SCCF, Sanibel-Captiva Conservation Foundation; SRWMD, Suwannee River Water Management District; TBEP, Tampa Bay Estuary Program; TNC, The Nature Conservancy; UF, University of Florida; UM RSMAS, University of Miami Rosenstiel School of Marine and Atmospheric Science; UNH, University of New Hampshire; USACE, U.S. Army Corps of Engineers; USF, University of South Florida; USGS, U.S. Geological Survey]

\begin{tabular}{|c|c|c|}
\hline Name & Affiliation & Email \\
\hline Jeffrey Reidenauer & BOEM & jeffrey.reidenauer@boem.gov \\
\hline Lora Turner & BOEM & lora.turner@boem.gov \\
\hline Joellen Wilson & Bonefish \& Tarpon Trust & jwilson@bonefishtarpontrust.org \\
\hline Jon Arthur & DEP-FGS & Jonathan.Arthur@dep.state.fl.us \\
\hline Dan Phelps & DEP-FGS & Dan.Phelps@dep.state.fl.us \\
\hline Kevin Owen & ERT & kevin.owen@noaa.gov \\
\hline Christopher Williams & FDEP & Christopher.P.Williams@dep.state.fl.us \\
\hline Jennifer Steele & FDEP & Jennifer.K.Steele@dep.state.fl.us \\
\hline Mary Esposito & FDEP & Mary.Esposito@dep.state.fl.us \\
\hline Libby Fetherston-Resch & FIO & ehfetherston@usf.edu \\
\hline Phil Kramer & FIO & philipkramer@usf.edu \\
\hline Ivor Mollema & FL DOS & ivor.mollema@dos.myflorida.com \\
\hline Jessica Joiner & FL Health & jessica.joiner@flhealth.gov \\
\hline Sandra Brooke & FSU & sbrooke@fsu.edu \\
\hline Amber Whittle & FWC & Amber.Whittle@MyFWC.com \\
\hline Anthony Knapp & FWC & Anthony.Knapp@MyFWC.com \\
\hline Brad Ennis & FWC & Bradley.Ennis@MyFWC.com \\
\hline Renee Duffey & FWC & Renee.Duffey@MyFWC.com \\
\hline Ryan Druyor & FWC & Ryan.Druyor@MyFWC.com \\
\hline Sean Keenan & FWC & Sean.Keenan@MyFWC.com \\
\hline Dave Reed & FWC/FWRI & Dave.Reed@MyFWC.com \\
\hline Rene Baumstark & FWC/FWRI & Rene.Baumstark@MyFWC.com \\
\hline Ryan Moyer & FWC/FWRI & Ryan.Moyer@MyFWC.com \\
\hline Laura Bowie & GOMA & laura.bowie@gomxa.org \\
\hline Ali Robertson & GOMA & ali.robertson@gomxa.org \\
\hline Keith Kolasa & Hernando County & kkolasa@hernandocounty.us \\
\hline Arnold Kravitz & IDS & akravitz@idstech.us \\
\hline Kathy Goodin & NatureServe & Kathy_Goodin@natureserve.org \\
\hline David Dale & NMFS SERO & david.dale@noaa.gov \\
\hline Carrie Wall & NOAA & Carrie.Bell@colorado.edu \\
\hline Kent Smith & NOAA & kent.smith@myfwc.com \\
\hline Kris Kaufman & NOAA & Kristen.Kaufman@noaa.gov \\
\hline Kyle Ward & NOAA & Kyle.Ward@noaa.gov \\
\hline
\end{tabular}




\begin{tabular}{|c|c|c|}
\hline Name & Affiliation & Email \\
\hline Mark Sramek & NOAA & mark.sramek@noaa.gov \\
\hline Mike Aslaksen & NOAA & mike.aslaksen@noaa.gov \\
\hline Randy Clark & NOAA & randy.clark@noaa.gov \\
\hline Steve Giordano & NOAA & steve.giordano@noaa.gov \\
\hline Tim Battista & NOAA & tim.battista@noaa.gov \\
\hline Tim Osborn & NOAA & tim.osborn@noaa.gov \\
\hline Wayne Wright & NOAA & lidar532@gmail.com \\
\hline Amanda Frick & NOAA SERO & amanda.frick@noaa.gov \\
\hline Paul Turner & NOAA-IOCM & paul.turner@noaa.gov \\
\hline Karen Kebart & NW FL Water Management District & Karen.Kebart@nwfwater.com \\
\hline Bernhard Riegl & NOVA & rieglb@nova.edu \\
\hline Brian Walker & NOVA & walkerb@nova.edu \\
\hline Rebecca Beavers & NPS & rebecca_beavers@nps.gov \\
\hline Chris Robbins & Ocean Conservancy & crobbins@oceanconservancy.org \\
\hline Eric Milbrandt & SCCF & emilbran@sccf.org \\
\hline Darlene Valez & SRWMD & Darlene.Velez@srwmd.org \\
\hline Gary Raulerson & TBEP & graulerson@tbep.org \\
\hline Laura Geselbracht & $\mathrm{TNC}$ & lgeselbracht@TNC.ORG \\
\hline Peter Adams & UF & adamsp@ufl.edu \\
\hline Gregor Eberli & UM RSMAS & geberli@rsmas.miami.edu \\
\hline Larry Mayer & UNH & larry@ccom.unh.edu \\
\hline Clay McCoy & USACE & Clay.A.McCoy@usace.army.mi \\
\hline Jennifer Wozencraft & USACE & Jennifer.M.Wozencraft@usace.army.mil \\
\hline Chad Lembke & USF & clembke@usf.edu \\
\hline Chuanmin $\mathrm{Hu}$ & USF & huc@usf.edu \\
\hline Daniel Otis & USF & dotis@mail.usf.edu \\
\hline David Naar & USF & naar@usf.edu \\
\hline E. A. Shinn & USF & eugeneshinn@usf.edu \\
\hline Grace Han & USF & xingxinghan@mail.usf.edu \\
\hline Greg Herbert & USF & gherbert@usf.edu \\
\hline John Gray & USF & jwgray@mail.usf.edu \\
\hline Matt Hommeyer & USF & mhommeyer@mail.usf.edu \\
\hline Sarah Grasty & USF & grastys@mail.usf.edu \\
\hline Steven Murawski & USF & smurawski@usf.edu \\
\hline Xan Fredericks & USGS & afredericks@usgs.gov \\
\hline Cheryl Hapke & USGS & chapke@usgs.gov \\
\hline James Flocks & USGS & jflocks@usgs.gov \\
\hline Jeffrey Danielson & USGS & daniels@usgs.gov \\
\hline Jennifer Miselis & USGS & jmiselis@usgs.gov \\
\hline Nicholas Enwright & USGS & enwrightn@usgs.gov \\
\hline Samuel Johnson & USGS & sjohnson@usgs.gov \\
\hline Stan Locker & USF & stan@usf.edu \\
\hline Mike Zoltek & Woolpert & Mike.Zoltek@Woolpert.com \\
\hline
\end{tabular}




\section{Appendix 2. Members of the Steering Committee and Technical Teams Steering Committee}

Table 2.1. Steering committee members and affiliations, 2017-18.

[USGS, U.S. Geological Survey; FIO, Florida Institute of Oceanography; FDEP, Florida Department of Environmental Protection; GIO, Geographical Information Officer; FGS, Florida Geological Survey; FWRI, Fish and Wildlife Research Institute; FDEM, Florida Division of Emergency Management; NOAA, National Oceanic and Atmospheric Administration; FAU, Florida Atlantic University; USACE, U.S. Army Corps of Engineers; BOEM, Bureau of Ocean Energy Management]

\begin{tabular}{ll}
\hline \multicolumn{1}{c}{ Name } & \multicolumn{1}{c}{ Affiliation } \\
\hline Cheryl Hapke (co-chair) & USGS \\
Phil Kramer (co-chair) & FIO \\
Ekaterina Fitos (co-chair) & FDEP/GIO \\
Jon Arthur & FDEP/FGS \\
Rene Baumstark & FWRI \\
Richard Butgereit & FDEM \\
Ashley Chappell & NOAA \\
Fraser Dalgleish & FAU \\
Clay McCoy & USACE \\
Jeff Reidenauer & BOEM \\
Jennifer Wozencraft & USACE \\
Xan Fredericks & USGS \\
\hline
\end{tabular}

Table 2.2. Technical team and affiliations, 2017.

[FIO, Florida Institute of Oceanography; NOAA, National Oceanic and Atmospheric Administration; FWRI, Fish and Wildlife Research Institute; EPA, U.S. Environmental Protection Agency; USGS, U.S. Geological Survey; USF, University of South Florida; USACE, U.S. Army Corps of Engineers; BOEM, Bureau of Ocean Energy Management; FGS, Florida Geological Survey; UM, University of Miami; NOVA, Nova Southeastern University]

\begin{tabular}{ll}
\hline \multicolumn{1}{c}{ Name } & \multicolumn{1}{c}{ Affiliation } \\
\hline Elizabeth Fetherston-Resch (lead) & FIO \\
Tim Battista & NOAA \\
Rene Baumstark & FWRI \\
Gary Collins & EPA \\
Xan Fredericks & USGS \\
Matt Hommeryer & USF \\
Stan Locker & USF-CMS \\
Clay McCoy & USACE \\
Mike Miner & BOEM \\
Mark Monaco & NOAA \\
Dan Phelps & FGS \\
Sam Purkis & UM \\
Jeff Waldner & BOEM \\
Brian Walker & NOVA \\
\hline
\end{tabular}




\section{Appendix 3. Agenda of the January 2018 Workshop}

\section{Florida Coastal Mapping Program Workshop Agenda}

January 9 to 11, 2018, Meeting

Florida Fish and Wildlife Research Institute, St. Petersburg, Florida

\section{Meeting goals:}

- Vet the technical team's mapping footprint with participants - what is missing? (U.S. Geological Survey volunteers will be on hand to help people enter additional information.)

- Get consensus around minimum mapping resolution for Florida waters from 0 to 200 meters $(\mathrm{m})$

- Set the stage for a subsequent prioritization process for six Florida subregions

- Determine the appropriate role for Florida Coastal Mapping Program (FCMaP) going forward

\section{January 9-Introduction to the FCMP (Auditorium)}

1:00 Welcome and overview of the vision and mission, presentation of FCMaP organizational chart (Cheryl Hapke)

1:20 Why bathymetric mapping should be a priority in Florida (perspectives from Florida Representative Charlie Crist's office)

1:30 Program purpose and need (Phil Kramer)

- Background on other Florida mapping initiatives

- Why high-resolution bathymetry (right now)?

- Application of bathymetry to Florida's coastal economy and research

2:00 Importance of mapping to FCMaP partner agencies

U.S. Geological Survey, Florida Institute of Oceanography, National Oceanic and Atmospheric Administration (NOAA), Florida Department of Environmental Protection, ACOE, Florida Fish and Wildlife Conservation Commission, and Bureau of Ocean Energy Management; 5 minutes each

Panel $Q$ and $A$ (facilitated by Libby Fetherston-Resch)

3:00 Coffee break (outside auditorium)

3:30 Introduction to the new 3D Nation Survey effort (Ashley Chappell/Paul Turner)

4:00 Description of the technical team efforts to assemble existing mapping data (Libby Fetherston-Resch/Rene Baumstark)

Technical team process

Big picture goals and participants

Process of narrowing to minimum data standards

Florida Fish and Wildlife Research Institute (FWRI) display portal

Presentation of the mapping gaps

4:30 Deep dive into benthic habitat areas of critical importance (Steve Murawski)

5:00 Day 1 wrap-up (Phil Kramer), dinner on your own 


\section{January 10-Prioritization Tools and Break-Out Discussions (Begins in Auditorium)}

7:30 Breakfast provided (outside auditorium)

8:30 Overview of mapping success in other regions

Washington State/NOAA prioritization tool and NOAA mapping prioritization in the Southeast (Tim Battista); 45 min

The California Seafloor Mapping Program-History, Challenges, Applications, and Lessons Learned (Sam Johnson); 45 min

Overview of Seabed 2030 and SeaSketch Tool (Paul Turner/Ashley Chappell); $30 \mathrm{~min}$

10:30 Coffee break (outside auditorium)

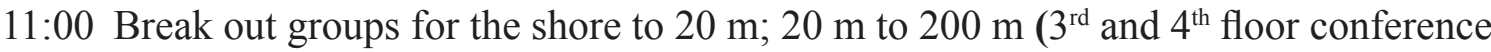
rooms). Morning objective: vet the FCMP effort to capture existing mapping coverage. Add mapping footprints as necessary.

12:30 Lunch (outside $3^{\text {rd }}$ floor conference room) with optional working lunch on legacy data in the 4th floor classroom

1:30 Afternoon break-out group objectives (same groups, same conference rooms: shore to $20 \mathrm{~m} ; 20 \mathrm{~m}$ to $200 \mathrm{~m}$ ): Develop consensus around a Florida-wide goal; describe what it would take to raise Florida bathymetric root data up to the target resolution.

Break-out group agenda:

- Define important resources, who maps there and why.

- Discuss and determine the minimum resolution necessary to meet the need.

- What sensors, what amount of effort, and over what time?

- Full mapping coverage or interpolate? What about a ground-truthing strategy?

- Is there a temporal component to mapping to consider (best time of year for satellite images, multibeam surveys, and so on)?

- What is the desired re-mapping frequency? Is there a role for citizen science?

- Vet the spatial boundaries for subsequent regional prioritization process.

3:00 Coffee break (outside auditorium)

4:30 Regroup to discuss breakout group efforts, address concerns, day 2 wrap-up (Libby Fetherston-Resch/Xan Fredericks, auditorium)

6:00 Evening reception at the nearby Marine Exploration Center 


\section{January 11-Coordination and Collaboration for Florida Mapping ( $3^{\text {rd }}$ Floor Conference Room)}

7:30 Breakfast provided outside auditorium

9:00 Irma-specific coordination effort mini-session (Cheryl Hapke and Ashley Chappell)

10:00 Group discussion: making the Florida-wide case for mapping to a minimum standard (Libby Fetherston-Resch)

- Should we engage in a coordinated effort to secure a consistent, high quality bathymetric map of Florida's waters?

- Do we need a legislative strategy for securing funding? Are there other targets?

- Should there be a central state hub for mapping coordination (for example, post-disturbance response and recovery)? How best to staff this effort?

10:30 Coffee available outside auditorium, meeting will not break however

11:00 Regional prioritization process going forward (Libby Fetherston-Resch)

Regional prioritization workshops in each of the six Florida regions to capture stakeholder mapping priorities (where and when), necessary types of data (Bathymetric maps? Different resolutions? Derived products? Others?), and the different reasons and justification for mapping in a specific region.

Implement a formal prioritization process for mapping in Florida? Vet the output of these processes with meeting participants? Combine into a single, Florida mapping priorities document?

12:00 Meeting wrap up and next steps (Phil Kramer)

Boxed lunches to-go (outside $3^{\text {rd }}$ floor conference room) 


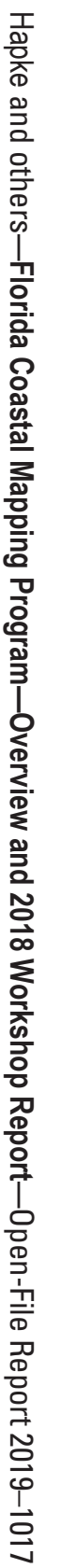

